\title{
Impacts of Bush Management on Herbaceous Plant Diversity and Biomass and, Soil Organic Carbon and Nitrogen in Borana Rangelands, Southern Ethiopia
}

\author{
Siraj Kelil Gobelle \\ Agroforestry Research Team, Oromia Agricultural Research Institute, Yaballo Pastoral and Dryland Agriculture Research Center, Yaballo, \\ Ethiopia
}

Email address:

kelilsiraj2012@gmail.com

To cite this article:

Siraj Kelil Gobelle. Impacts of Bush Management on Herbaceous Plant Diversity and Biomass and, Soil Organic Carbon and Nitrogen in Borana Rangelands, Southern Ethiopia. Journal of Plant Sciences. Vol. 9, No. 2, 2021, pp. 38-45. doi: 10.11648/j.jps.20210902.12

Received: August 17, 2020; Accepted: September 7, 2020; Published: April 23, 2021

\begin{abstract}
Bush thinning or clearing rangeland management practice in Borana rangelands considered to have a high potential to improve rangeland productivities and soil conditions, yet few studies have quantified the impacts of bush management on herbaceous plants species diversity, biomass and soil Organic Carbon and Nitrogen contents. This study was conducted in Yaballo (Hara-woyu Kebele) and Taltale (Sarite kebele) Woreda of Borana zone, to evaluate the impacts of bush management (thinning) on herbaceous plant species composition, diversity, biomass and some selected soil physicochemical properties. Data were collected from bush thinned and bush encroached rangeland management classes at both sites. Sampling plots were placed systematically along the geographic gradient in both of the rangeland management classes at both study sites. Within all plots, herbaceous plants were identified and clipped to the ground, collected and oven-dried to determine biomass. Herbaceous plant species, diversity, biomass and soil organic carbon contents and soil carbon stock were higher under Bush managed (thinned) class compared to bush encroached. However, bush management (thinning) have not shown considerable effects on soil bulk density, $\mathrm{pH}$, nitrogen contents and total nitrogen stock. Thus, understory vegetation and soil organic carbon were influenced by the presence of thinning, but soil bulk density, $\mathrm{pH}$, nitrogen contents were not influenced by thinning in this study. Generally, bush management (thinning) increased the rangeland condition, however; the management is not sustainable in case the thinning practice is not followed recommended procedures because most of the encroacher species are sprout more densely within a short time.
\end{abstract}

Keywords: Bush Encroachment, Bush Thinned, Rangeland Management Class, Soil Organic Carbon Stock, Herbaceous Plant Diversity, Biomass, Soil Nitrogen Stock

\section{Introduction}

Rangeland and savanna ecosystems are characterized by the coexistence of trees, shrubs and grasses. The mechanisms permitting the co-existence of trees and grass in Savannas are determined by competition for resources or differential sensitivity to disturbance of the two growth forms [1]. The co-existence of trees and grass is due to the simultaneous influence of rainfall and fire. In the increased rainfall savanna (moist savanna) the co-existence of trees and grasses can only occur in the presence of a high level of fire disturbance [1]. This cohabitation of trees and grass in savanna ecologies provides comprehensive economic and ecological benefits to pastoralist communities [2]. Nevertheless, the productivity and long-term economic viability, as well as the ecological integrity of savanna and grasslands are being weakened by increasingly dense thickets of woody vegetation often named as bush encroachments.

Bush encroachment can be defined as the increase in density, cover, and biomass of indigenous woody or shrubby plants and it is a widely spread phenomenon that has the global trans-national nature, particularly visible in African savannas and grasslands $[3,4,5,6]$. Like other African rangelands, most of the rangelands of Ethiopia are currently being affected by woody plant encroachments. The Borena rangelands, located in the southern part of the country are 
among the areas that are heavily being affected by bush encroachments since the Gada Liiban Jaldesa [7, 8, 9, 10]. In the mid-1980s, about $40 \%$ of the Borana rangelands were affected by bush encroachment and its cover and density increasing from year to year at high rates [9, 11, 12, 13]. Moreover, the challenge of bush encroachment is that it has highly encroached into the bottomland where the soil is favorable for grasses production.

In areas where grazing by cattle and sheep has been the primary land use, woody plant encroachments have typically been viewed as rangeland degradations and it is the fundamental motivation for bush management. In Borana rangelands, bush encroachment is considered as one of the major problems affecting rangeland ecosystem structures and functions. Several studies [7, 9, 14, 15] have reported the adverse effects of woody plant encroachments on grasses' productivity. Furthermore, it hampered the diversity of the native vegetation, particularly the grasses and forbs and reduced ground cover, exposing large parts of the rangelands for soil erosion and other degradation processes [12, 16], which results in chronic overgrazing.

To overcome or mitigate the effects, pastoralists started an approach of bush management (thinning/clearing of the woody plant species). Varies kinds of bush management technologies including mechanical treatments, herbicides, prescribed fire and biocontrol agents were practicing $[17,18$, 16]. Despite considerable investments accompanying the application of bush encroachment management practices, the recovery of key ecosystem services may be short-lived or absent. However, in the absence of such interventions, these and other ecosystem services may be compromised, and the persistence of grassland and savanna and their endemic plants and animals threatened [19]. Studies in Borana rangelands show that bush managements such as bush cutting and fire, bush cutting followed by fire and grazing, and the old traditional method of fire and grazing improved herbaceous biomass accumulation, basal cover and species diversity while grazing with bush cover greatly reduced herbaceous biomass $[14,18]$. Controlling encroaching shrubs species create conducive grazing areas with palatable herbaceous species for livestock [16]. Maintaining the productivities of rangelands requires knowledge of how herbaceous vegetation and soil responds to bush management.

\section{Methods}

\subsection{Description of the Study Area}

This study was conducted in the Borana Zone of southern Ethiopia with a total area of approximately $44,000 \mathrm{~km}^{2}$. The landscape is slightly undulating that elevation ranges from 500 to 2,500 $\mathrm{m}$ above sea level [13]. The Zone has thirteen (13) administration Woreda. This study was carried out in Hara woyu and Sarite specific study sites with the geographical location of $43942.24 \mathrm{E} ; 380238 \mathrm{~N}$, and 1260.08 m.a.s.l and $45591.18 \mathrm{E} ; 354330.9 \mathrm{~N}$ and 974.69 m.a.s.1 respectively.

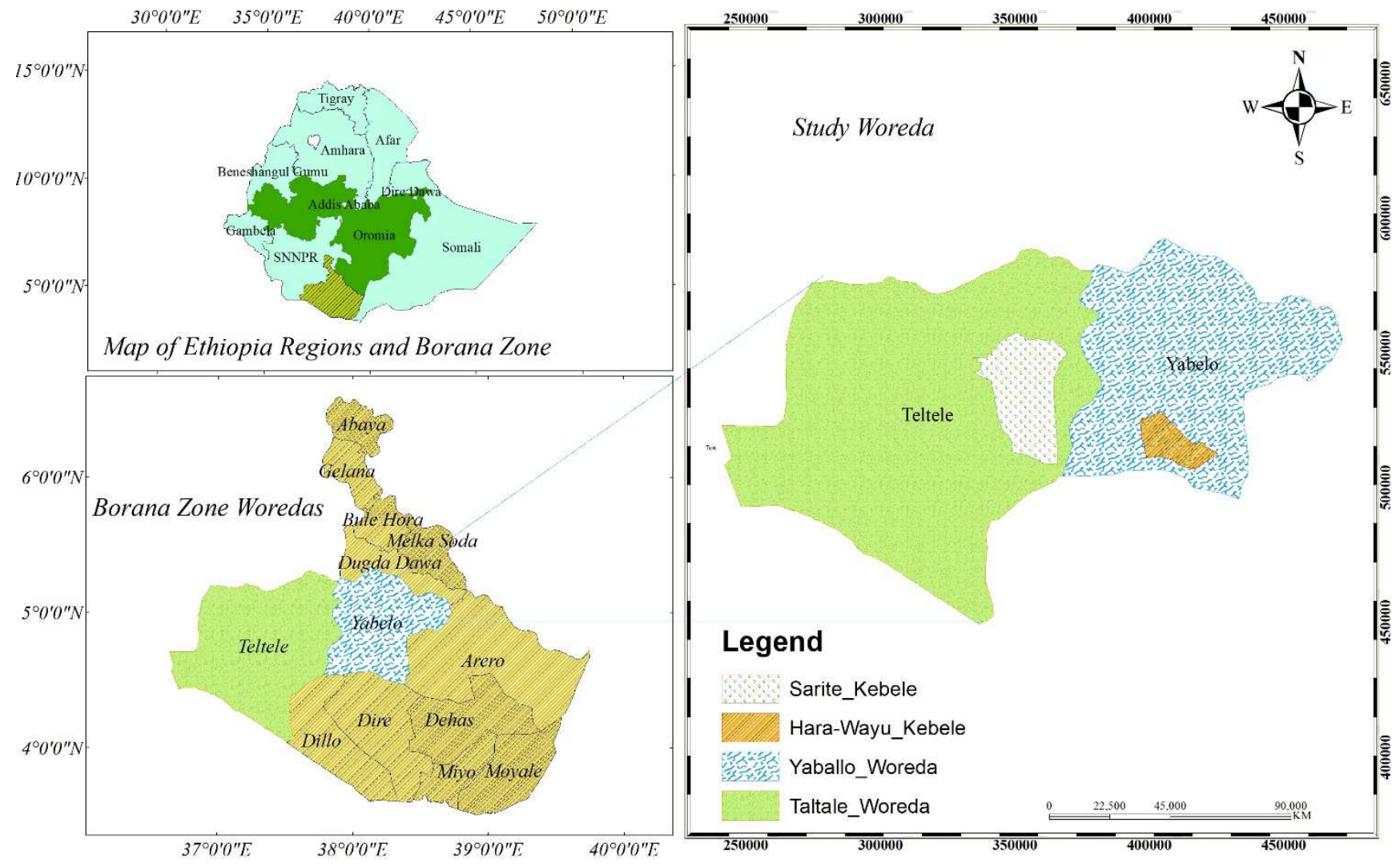

Figure 1. Map of study area showing study Woreda and kebeles (Sarite and Hara woyu). 
The Climate of the Zone is largely semi - arid with maximum temperatures ranged from 26 to $28^{\circ} \mathrm{C}$ and the minimum from 11 to $15^{\circ} \mathrm{C}$. The rainfall pattern of the zone is characterized by erratic and distinctly bimodal. 59\% of annual precipitation occurs from March to May, while $27 \%$ occurs from September to November [7], and the cool dry season from June to August. The mean annual rainfall ranges from $300 \mathrm{~mm}$ in the lowlands to $1,000 \mathrm{~mm}$ in the midhighlands with a high coefficient of variability ranging from $18 \%$ to $69 \%$ [15].

The central Borana plateau comprises of four basic geological formations; Pre Cambrian basement complex $(38 \%)$, sedimentary deposits $(2 \%)$, and volcanic (20\%) and quaternary deposits (40\%) [7]. These factors influence soil fertility which in turn, influences the vegetation characteristics. Borana rangelands comprise of three main soils; $53 \%$ red sandy loam soil, $30 \%$ black clay and volcanic light-colored silty clay and $17 \%$ silty [7]

The major land cover of Borana zone is characterized under Acacia-Commiphora woodland and bushland and floristically, this vegetation type is the most diverse with the highest number of species and varieties that are not shared with other vegetation types [20]. However, currently shifting from grassland savanna to bush and shrubland [11, 13].

The largest parts of communities living in Borana zone are pastoralists. Almost all household producing both large and small livestock, so livestock production is very important to livelihoods [7, 11]. Borana communities managing their rangelands as enclosures (Kalo) and open grazing communal rangelands in which livestock grazing though out the year [7]. The expansion of bush encroachment into the rangelands decreases the carrying capacity for livestock such as cattle and sheep thereby reducing the livelihood of pastoralists. As a result, the large scale physical bush clearing/thinning practices in different areas of the Zone by Gov.t and NGOs. Thus, made an ideal setting to select independent treatment replicates across the study areas.

Table 1. Location, climate and major encroacher bush species of the study sites.

\begin{tabular}{|c|c|c|c|c|c|c|c|}
\hline Sites & Latitude & Longitude & Elev. & MAP & Mean temp. & Rangeland History & Major encroachers and thinned species \\
\hline Hara-woyu & $04^{0} 39^{\prime} 55^{\prime \prime} \mathrm{N}$ & $38^{0} 02^{\prime} 36^{\prime \prime} \mathrm{E}$ & 1257 & 835 & 20 & Pure grassland & $\begin{array}{l}\text { Senegalia mellifera, Vachellia reficiens and } \\
\text { Commiphora africana }\end{array}$ \\
\hline Sarite & $04^{0} 55^{\prime} 11^{\prime \prime} \mathrm{N}$ & $37^{0} 41^{\prime} 03^{\prime \prime} \mathrm{E}$ & 976.5 & 538.6 & 22.1 & Pure grassland & $\begin{array}{l}\text { Senegalia mellifera, Vachellia reficiens and } \\
\text { Vachellia oerfota }\end{array}$ \\
\hline
\end{tabular}

Mean temp $=$ mean annual temperature $\left({ }^{\circ} \mathrm{C}\right), \mathrm{MAP}=$ mean annual precipitation $(\mathrm{mm})$, Elev. $=$ elevation in meters above sea level.

\subsection{Sampling Design and Data Collection}

The two study sites were purposively selected because of the presence of two rangeland management class (bush managed and bush encroached) found in the same area. At each rangeland types, the transect lines were systematically placed along a geographic gradient. Square shaped sampling plots having a size of $20 \mathrm{~m}$ x $20 \mathrm{~m}$ was used for plant diversity study and soil sampling were systematically placed along the transect lines at about $100 \mathrm{~m}$ intervals. Within larger plots, three $1 \mathrm{~m} \times 1 \mathrm{~m}$ plots were placed along the diagonal line of the larger plot and used for herbaceous data collection. Soil samples were collected from the four corners and the center of the $20 \mathrm{~m} \times 20 \mathrm{~m}$ plots (main plot) at the depth of 0 $15 \mathrm{~cm}$ and $16-30 \mathrm{~cm}$ and one additional soil sample was taken from the center of the main plots at the depth of $0-15 \mathrm{~cm}$ and $16-30 \mathrm{~cm}$ for bulk density determination. 24 main sample plots, 6 from each rangeland management class of both sites were used for data collection.

\subsubsection{Soil Sampling and Laboratory Analysis}

Soil samples were collected from the four corners and center of the main plots using motorized soil auger at two depths $(0-15 \mathrm{~cm}, 16-30 \mathrm{~cm})$. Soil samples taken from a similar depth of the same plot bulked to gather to form a composite sample and prepared for physiochemical analysis. Besides, one soil sample was taken from the center of each main plot at $0-15$ and $16-30 \mathrm{~cm}$ soil depth to determine bulk density. The soil samples were stored in labelled polyethylene plastic bags and taken to the Yaballo Pastoral and Dry land Agriculture Research Center soil laboratory.

The soil samples were air-dried, ground in a mortar, sieved using $2 \mathrm{~mm}$ size sieve and, analyzed for its carbon and nitrogen contents, $\mathrm{pH}$ and texture at Yaballo Pastoral and Dry Land Agricultural Research Center soil laboratory.

Soil bulk density ( $\rho b)$ was determined by the core method [21]. To reduce the overestimation of soil carbon and nitrogen stock for coarse materials, coarse material, and roots $>2 \mathrm{~mm}$ were removed and soil bulk density was calculated as [22]. In this (equation 1), coarse fragments volume (cfv) was estimated as the mass of coarse fragments (g) per density of rock fragments $\left(\mathrm{g} / \mathrm{m}^{3}\right)$ and the density of rock fragments is often given as $2.65 \mathrm{~g} / \mathrm{cm}^{3}$ [22].

$$
\text { Soil bulk density }\left(\frac{\mathrm{g}}{\mathrm{m}^{3}}\right)=\frac{\text { Oven dry mass }\left(\frac{\mathrm{g}}{\mathrm{m}^{3}}\right)}{\operatorname{Core} \operatorname{volume}\left(\mathrm{m}^{3}\right)-\mathrm{cfv}\left(\mathrm{m}^{3}\right)}
$$

Soil carbon concentration was determined using standard method; by Walkey-Black procedure (a wet combustion of organic matter with a mixture of potassium dichromate and sulfuric acid and residual potassium dichromate titrated against ferrous sulfate) $[23,24]$. Carbon stock or the amount of carbon per unit area was calculated as the products of soil carbon concentration, bulk density and soil depths (equation 2) $[25,22 ; 26]$. In this calculation, $\% \mathrm{C}$ converted to decimal fractions. 


$$
\operatorname{SOC}\left(\frac{\mathrm{t}}{\mathrm{ha}}\right)=\rho \mathrm{b}(\mathrm{g} / \mathrm{cm}-3) * \mathrm{C}(\%) * \text { soil depth }(\mathrm{cm}) * 100
$$

Total nitrogen content was determined following Kjeldahl method $[25,24]$ and the amount of total nitrogen per hectare was estimated as:

$$
\text { Total } \mathrm{N}\left(\frac{\mathrm{t}}{\mathrm{ha}}\right)=\operatorname{total} \mathrm{N}(\%) * \rho \mathrm{b}(\mathrm{gcm}-3) \text { soil depth }(\mathrm{cm}) * 100
$$

Soil $\mathrm{pH}$ was determined using a suspension of 1:5 soils to water ratio. Particle size analyses were done using the Hydrometer method.

\subsubsection{Vegetation Data Collection and Identification}

In $1 \mathrm{mx} 1 \mathrm{~m}$ subplots, all herbaceous plants were identified, counted, and recorded. The whole herbs, grasses, seedling, and climbers were clipped to the ground separately as grass and non-grass after the species were identified. The Fresh weight was taken immediately in the field using field balance and sub-samples were taken where the sample was too large to manage in oven dry. For a small and manageable sample, the whole samples were stored in polyethylene bags and taken to Yaballo Pastoral and Dryland Agriculture Research Center soil laboratory and oven-dried for 24 hours at $105^{\circ} \mathrm{C}$ to determine the biomass and carbon stock.

Identification of the species was made in the field with the help of local key informants, field identification keys, from previous studies conducted in the study areas like [27] and using plants and Flora of Ethiopia books [28, 29]. The plant species that were difficult to identify in the field the specimens were collected from the sample plots and identified at Ethiopia biodiversity herbarium at Addis Ababa.

Measurement of diversity indices

The formula for calculating the Shannon diversity index is:

$$
\mathrm{H}^{\prime}=-\sum_{\mathrm{i}=1}^{\mathrm{S}} \mathrm{P}_{\mathrm{i}} * \ln \mathrm{P}_{\mathrm{i}}
$$

Where, $H^{\prime}=$ Shannon index of diversity; $\Sigma=$ Summation symbol; = total number of species in the sample; $\mathrm{pi}=$ the proportion of the $i^{\text {th }}$ species $\left(p i=n_{i} / N\right), n_{i}=$ abundance of $i^{\text {th }}$ species and $\mathrm{N}=$ total number of individuals and $\ln =\log$ bases (natural logarithms).

Dominance and Simpson index were calculated as:

$$
D=\sum_{i}^{S}\left(P_{i}\right)^{2} \text { and Simpson index }=1-\mathrm{D}
$$

Where, $D=$ Simpson index of dominance, $\left(p i=n_{i} / N\right), n_{i}=$ abundance of $\mathrm{i}^{\text {th }}$ species and $\mathrm{N}=$ total number of individuals.

Evenness or equitability index was calculated as:

$$
\mathrm{E}=\left(\mathrm{H}^{\prime}\right) / \ln \mathrm{S}=\left(\mathrm{H}^{\prime}\right) /\left(\mathrm{H}^{\prime} \max \right)
$$

Where: $\mathrm{E}=$ Evenness; $\mathrm{H}^{\prime}=$ Shannon-Wiener Diversity Index; $H \max =\ln (S)$.

\subsection{Methods of Data Analysis}

The herbaceous plant species diversity of the rangeland management classes were analyzed using PAST version 3.10, Paleontological Statistical software [30]. Before analysis, the data were tested for normal distribution using SPSS version 20 following Shapiro-Wilk methods. The herbaceous plant diversity, biomass and soil results were analyzed using General Linear Model (GLM) procedures. Two way analysis of variance (study sites, and rangeland management class) was used to analysis the data, and Tukey HSD (at $P<0.05$ ) was used to test for possible statistically significant mean pair separation.

\section{Results and Discussion}

\subsection{Herbaceous Plant Diversity}

The similarity in herbaceous plant species diversity between the two study sites and rangeland management classes were evaluated. The two study sites (Hara-wayu and Sarite) were not significantly different in herbaceous plant species richness, Shannon and Simpson diversity index. However, the rangeland management classes (bush encroached and bush thinned) were significantly different in terms of herbaceous plant diversity (Table 2). The herbaceous plant species richness in bush thinned rangeland

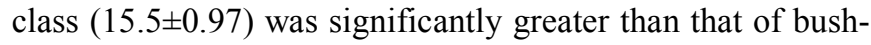
encroached land (6.0 \pm 0.97$)$. Shannon diversity index was also greater in bush thinned areas $(2.0 \pm 0.09)$ compared to bush encroached rangeland class $(1.14 \pm 0.09)$. Furthermore, the herbaceous Simpson diversity index was better in bush managed than bushes encroached (Table 2). The increasing in woody plant density beyond a critical density border is reduce the understory herbaceous plant species richness and diversity [31]. The herbaceous plant evenness was not significantly different between the study sites and rangeland management classes. These findings are agreed with other studies in Borana rangeland showed bushes management increase herbaceous plant species diversity and richness $[8$, $18,32]$. Similarly, a study in the south Omo zone showed bushes controlling through mechanical technique, and leaving the cleared material on sites promote the herbaceous plant species richness and composition [33]. A study in South Africa indicated mechanical bushes thinning increase the grasses and other perennial plant species richness and diversity [34]. Another study also found that the removal of encroacher species is increasing herbaceous plant species diversity and evenness, and underscore the importance of decisive management for reversing the effects of woody plant encroachment in imperiled grassland ecosystems [35]. The increases in herbaceous plant covers and productions following brush management is due to the woody plant encroachment hurt ground cover [35]. This finding in line with a study that showed understory vegetation is influenced by the presence of thinning [39]. 
Table 2. Means ( \pm standard error) of herbaceous cover, species richness, Shannon index (H), Simpson and evenness and, Litter cover of the two study sites and rangeland types $(n=24)$.

\begin{tabular}{|c|c|c|c|c|}
\hline \multirow{2}{*}{$\begin{array}{l}\text { Vegetation } \\
\text { variables }{ }^{1}\end{array}$} & \multicolumn{2}{|l|}{ Study sites } & \multicolumn{2}{|c|}{ Rangeland management class } \\
\hline & Hara-woyu & Sarite & Bush encroached & Bush thinned \\
\hline Herbaceous Richness (s) & $11.75 \pm 0.97^{\mathrm{a}}$ & $09.75 \pm 0.97^{\mathrm{a}}$ & $6.0 \pm 0.97^{\mathrm{b}}$ & $15.5 \pm 0.97^{\mathrm{a}}$ \\
\hline Herbaceous diversity $\left(\mathrm{H}^{\prime}\right)$ & $01.45 \pm 0.09^{\mathrm{a}}$ & $01.70 \pm 0.09^{\mathrm{a}}$ & $1.14 \pm 0.09^{b}$ & $2.0 \pm 0.09^{\mathrm{a}}$ \\
\hline Herbaceous evenness & $00.54 \pm 0.04^{\mathrm{a}}$ & $00.61 \pm 0.04^{\mathrm{a}}$ & $0.62 \pm 0.04^{\mathrm{a}}$ & $0.53 \pm 0.04^{\mathrm{a}}$ \\
\hline $\operatorname{Grass}_{\mathrm{AGB}}(\mathrm{t} / \mathrm{ha})$ & $00.21 \pm 0.03^{\mathrm{a}}$ & $00.23 \pm 0.03^{\mathrm{a}}$ & $0.02 \pm 0.03^{\mathrm{b}}$ & $0.42 \pm 0.03^{\mathrm{a}}$ \\
\hline Nan-grass ${ }_{A G B}(t / h a)$ & $00.21 \pm 0.04^{\mathrm{a}}$ & $00.08 \pm 0.04^{\mathrm{b}}$ & $0.04 \pm 0.04^{\mathrm{b}}$ & $0.26 \pm 0.04^{\mathrm{a}}$ \\
\hline
\end{tabular}

\subsection{Herbaceous Plant Production and Cover}

The herbaceous production and cover at the two study sites and in bush encroached and bush thinned rangeland classes were evaluated. The findings from this study indicated that grass aboveground biomass at the two study sites was not significantly different, but it was significantly different between bush encroached and bush thinned rangeland management class. The mean oven-dried grass aboveground biomass in bush-thinned rangeland management class was $0.42 \pm 0.03 \mathrm{t} / \mathrm{ha}$, which greater than that of bush encroachedrangeland class $(0.02 \pm 0.03 \mathrm{t} / \mathrm{ha})$. Whereas, non-grass aboveground biomass was significantly affected both by study sites and rangeland management classes. It was higher in Hara-woyu site $(00.21 \pm 0.04 \mathrm{t} / \mathrm{ha})$ than Sarite site $(00.08 \pm 0.04 \mathrm{t} / \mathrm{ha})$ and bush thinned (managed) rangeland class $(0.26 \pm 0.04 \mathrm{t} / \mathrm{ha})$ was greater than bush encroached rangeland class $(0.04 \pm 0.04 \mathrm{t} / \mathrm{ha})$. In terms of herbaceous plant ground cover, the study site was not significantly different, but it was significantly different between bush encroached and bush thinned (managed) rangeland class. The bush thinned (managed) rangeland class $(38.72 \pm 3.1 \%)$ was significantly greater than that of unmanaged rangeland class (Table 2). This finding agreed with studies conducted in southern parts of Ethiopia which showed bush thinning improved herbaceous plant dry matter biomass yields [35, 33]. Our results indicated that bush thinning increased the grasses above-ground dry matter yield by $95 \%$ and non-grass yield by $84.62 \%$. A study by [35] found that brush management conducted on productive rangeland sites increases herbaceous plant growth an average of 3 to 5 times. An other study in South Africa showed bush thinning increase the grasses dry matter yield, but forbs were negatively influenced by bush thinning [36]. The herbaceous production decline following bush encroachment might be due to the resource competition with woody encroachers. A study in the south Omo zone indicated that the understory herbaceous cover and biomass reduction following bush encroachment is associated with evergreen leaf phenology, shrubby growth form, smaller relative crown-base height and larger relative crown diameter nature of encroacher species [37].

Table 3. The Mean \pm SE of herbaceous parameters inaction effects of study sites and rangeland management class.

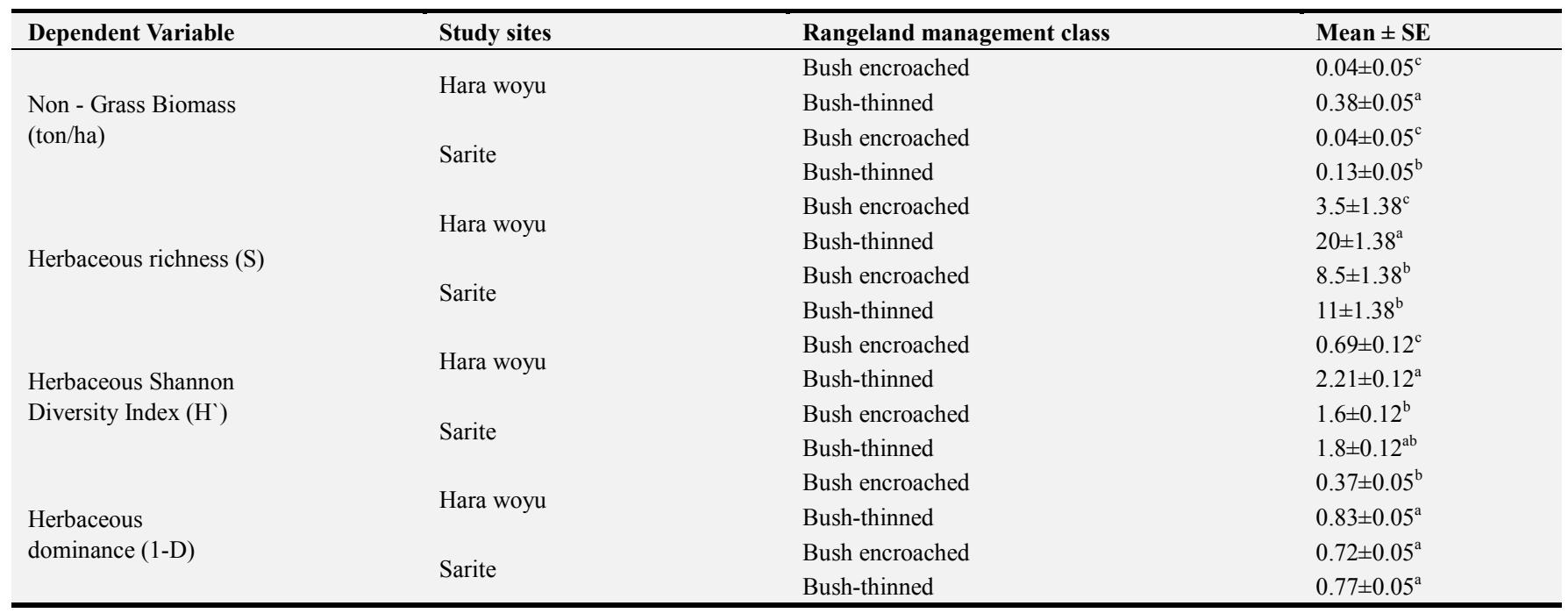

\subsection{Effects on Soil Organic Carbon and Nitrogen Stock}

The soil bulk density (BD) was no significantly varying between the study sites and rangeland management class $(P=$
0.117, $P=0.961$, respectively). The soil textural classes across the study sites and rangeland management classes were similar (clay) (Table 4). The result showed that the dominant in the study area was the clay mineral of the vertisols. This indicating that the inherent property of the 
study area was originated from the same parent materials.

The soil organic carbon and soil organic carbon stock were significantly different between the rangeland management class at both Hara-woyu and Sarite study sites and overall rangeland management class (Table 4). The soil organic carbon contents, soil organic matter and soil organic carbon stock were higher under bush thinned rangeland management class than bush encroached rangeland class at both sites and as overall rangeland management class. At Hara-woyu site the average soil organic carbon stock in bush thinned rangeland (54.42 $\pm 1.0 \mathrm{t} / \mathrm{ha}$ ) was significantly higher than bush-encroached rangeland class $(48.10 \pm 1.05 \mathrm{t} / \mathrm{ha})$. Similarly at Sarite site the average soil organic carbon stock in bush thinned rangeland management class $(33.8 \pm 1.05 \mathrm{t} / \mathrm{ha})$ was greater than that of bush-encroached rangeland class $(27.48 \pm 1.05 \mathrm{t} / \mathrm{ha})$. Moreover, the soil organic carbon content and carbon stock of overall rangeland management class in bush thinned rangeland $(44.11 \pm 0.86 \mathrm{t} / \mathrm{ha})$ was greater than bush encroached land (37.79 $\pm 0.8 \mathrm{t} / \mathrm{ha}$ ) (Table 4). At both sites, soil C stocks in bush thinned rangeland management class was greater by about $6.32 \mathrm{t} / \mathrm{ha}$ than bush encroached rangeland class. This is predominantly due to fine plant materials form thinning/cutting for rangeland management that has only partly decomposed and, improvement of herbaceous plant materials that return to soil annually. A study in the southern part of Ethiopia showed bushes clearing is improved range condition by increasing the basal cover of herbaceous plants thereby improving soil condition [8]. Bushes clearing and leaving the cleared material in the field rather burning reduced soil erosion and compaction [33]; consequently, increase the soil organic carbon and nitrogen stock.

The mean percent of the soil nitrogen content of the two studied rangeland management classes was not significantly different $(P=0.055)$. However, the total soil nitrogen stock of the two rangeland management classes was significantly different $(P=0.0497)$. The overall mean nitrogen stock in $30 \mathrm{~cm}$ soil depth was greater in bush-thinned raneland then bush-encroached rangeland types at both Hara-wayu and Sarite sites (Table 4). This may be due to the emerging of nitrogen-fixing herbaceous plant species following bush thinning and, nutrient leached sandy soils to a deeper soil profile, higher soil compaction and erosion rates in bush encroached sites. A review report by [43] stated that, in 161 savanna ecology across Africa, the woody cover showed a strong negatively correlated to soil $\mathrm{N}$ availability. This finding contrast with the result of [40] which revealed that the highest soil nitrogen content was recorded in the encroached site. The soil nitrogen content and the total soil nitrogen stock at Hara-woyu site were greater than that of Sarite site. The variation in soil nitrogen contents and stock of the two sites could be due to the variation in geographical gradient and precipitation. This finding is inlined with the study by [38] demonstrated that nitrogen deposition is negatively related to soil $\beta$-glucosidase and nitrogenize activities under extant conditions and this response is also dependent on superimposed environmental and geographical gradients.

The statistical analysis indicated that there was a significant difference in soil $\mathrm{pH}$ levels between the two study sites and rangeland management classes $(P<0.001, P=0.01$ respectively). The Sarite study site was more alkaline than Hara-woyu site. Under bush-thinned rangeland management class, the mean soil $\mathrm{pH}$ level was tended to lower than the bush-encroached at both sites and overall means (Table 4). This finding inlined with a study that showed the soil $\mathrm{pH}$ level in the controlled sites was slightly lower as compared to the uncontrolled sites [41]. Another similar finding was also reported by [42] who recorded higher soil $\mathrm{pH}$ levels in habitats with a denser trees canopy. This finding contrary to the study by [40], which indicated not any significant difference in $\mathrm{pH}$ levels between the bush-cleared and uncleared sites. The variation may be due to the variation in Argo-ecologies, variation in trees and herbaceous covers.

The mean percent clay, silt and sand contents of soils of the two study sites and rangeland management classes were statistically significantly different. However, their textural classes were similar (clay). The mean percent clay and silt content of the soil were better in the bush-thinned rangeland management class than the bush-encroached rangeland. Whereas, the mean sand content was greater in bushencroached rangeland class than bush-thinned (Table 4). This is maybe due to low herbaceous cover in bush-encroached rangeland which made the soil more susceptible to erosion. Soil erosion can modify soil properties by reducing soil depth, changing soil texture, and by the loss of nutrients and organic matter [44].

Table 4. Means and standard error of soil parameters of the two study sites and rangeland types $(n=24)$.

\begin{tabular}{|c|c|c|c|c|c|c|}
\hline \multirow{3}{*}{ Parameters } & \multicolumn{6}{|l|}{ Factors } \\
\hline & \multicolumn{2}{|l|}{ Hara-woyu } & \multicolumn{2}{|l|}{ Sarite } & \multicolumn{2}{|c|}{ Overall rangeland management class } \\
\hline & Bush thinned & Bush encroached & Bush thinned & Bush encroached & Bush thinned & Bush encroached \\
\hline Bulk D. $\left(\mathrm{gm} / \mathrm{cm}^{3}\right)$ & $1.20 \pm 0.03$ & $1.19 \pm 0.03$ & $1.15 \pm 0.03$ & $1.14 \pm 0.03$ & $1.17 \pm 0.02$ & $1.17 \pm 0.02$ \\
\hline Organic Carbon $(\%)$ & $1.51 \pm 0.03^{\mathrm{a}}$ & $1.34 \pm 0.03^{\mathrm{b}}$ & $0.98 \pm 0.03^{\mathrm{a}}$ & $0.81 \pm 0.031^{\mathrm{b}}$ & $1.25 \pm 0.02^{\mathrm{a}}$ & $1.08 \pm 0.02^{\mathrm{b}}$ \\
\hline Organic Mater $(\%)$ & $2.62 \pm 0.09^{\mathrm{a}}$ & $2.19 \pm 0.09^{b}$ & $1.75 \pm 0.09^{\mathrm{a}}$ & $1.33 \pm 0.09^{\mathrm{b}}$ & $2.19 \pm 0.07^{\mathrm{a}}$ & $1.76 \pm 0.07^{\mathrm{a}}$ \\
\hline Carbon Stock (t/ha) & $54.42 \pm 1.0^{\mathrm{a}}$ & $48.10 \pm 1.05^{\mathrm{b}}$ & $33.8 \pm 1.05^{\mathrm{a}}$ & $27.48 \pm 1.05^{\mathrm{b}}$ & $44.11 \pm 0.86^{\mathrm{a}}$ & $37.79 \pm 0.8^{\mathrm{b}}$ \\
\hline Nitrogen $(\%)$ & $0.12 \pm 0.004$ & $0.11 \pm 0.004$ & $0.09 \pm 0.004$ & $0.08 \pm 0.004$ & $0.11 \pm 0.003$ & $0.10 \pm 0.003$ \\
\hline Soil PH & $8.31 \pm 0.05^{\mathrm{b}}$ & $8.42 \pm 0.05^{\mathrm{a}}$ & $9.19 \pm 0.05^{\mathrm{b}}$ & $9.3 \pm 0.05^{\mathrm{a}}$ & $8.75 \pm 0.04^{b}$ & $8.86 \pm 0.04^{\mathrm{a}}$ \\
\hline Percent Clay (\%) & $44.28 \pm 2.25$ & $39.67 \pm 2.25$ & $56.41 \pm 2.25$ & $51.80 \pm 2.25$ & $50.35 \pm 1.83$ & $45.73 \pm 1.83$ \\
\hline Percent Silt (\%) & $18.72 \pm 1.34$ & $14.80 \pm 1.34$ & $23.18 \pm 1.34$ & $19.25 \pm 1.34$ & $20.95 \pm 1.09^{\mathrm{a}}$ & $17.03 \pm 1.09^{\mathrm{b}}$ \\
\hline Percent Sand (\%) & $36.99 \pm 2.81$ & $45.54 \pm 2.81$ & $20.41 \pm 2.81$ & $28.95 \pm 2.81$ & $28.70 \pm 2.30^{\mathrm{b}}$ & $37.24 \pm 2.30^{\mathrm{a}}$ \\
\hline Textural class & Clay & Clay & Clay & Clay & Clay & Clay \\
\hline
\end{tabular}




\section{Conclusions and Recommendation}

This paper provides the empirical pieces of evidence on the effects of bush-management on herbaceous plant species diversity and biomass and, soil organic carbon and nitrogen in Borana rangelands, Southern Ethiopia. The results showed a considerable difference between bush-thinned and bushencroached rangeland types in terms of herbaceous plant species diversity and biomass and soil organic carbon. Herbaceous plant species diversity and richness, and grasses and non-grasses biomass were significantly greater under bush thinned rangeland management compered to bush encroached rangeland. Furthermore, the study sites, and rangeland management classes were significantly different in terms of soil organic carbon nitrogen stocks, soil $\mathrm{pH}$ levels, and soil clay, silt and sand content. The soil organic carbon content and soil carbon stock within $30 \mathrm{~cm}$ soil depth was better in bush-thinned rangeland management class compered to bush-encroached rangeland types at both study sites. Likewise, The soil total nitrogen stock, clay content and silt content were greater in bush-thinned rangeland. Whereas, soil sand contents and soil $\mathrm{pH}$ levels were lower in bushthinned. These may indicate the good rangeland condition.

Overall, the study suggests that a substantial benefit of bush management for rangeland conditions (better herbaceous plants richness, diversity, ground cover and biomass (both grass and non-grass). Moreover, increased soil carbon and $\mathrm{N}$ pool, reduced soil $\mathrm{pH}$ levels, increased clay and silt contents and low sand contents of the soils) in Borana rangeland. Further investigations are needed on the economic benefits of bush thinning and utilization of woody encroachers for other uses as value addition activities in Borana rangelands.

\section{Acknowledgements}

The author would like to thanks the Yaballo Pastoral and Dryland Research Centre and its staff for helping and facilitating the fieldwork activities. I am grateful to Abiyot Lelisa for soil samples laboratory analysis. I also acknowledge Dr. Abdella Gure for constructive comments on an earlier version of this manuscript.

\section{Conflict of Interests}

The author declares no conflict of interest.

\section{References}

[1] Francesco Accatino, Carlo de Michele, Renata Vezzoli, Davide Donzelli, Robert J. Scholes (2010). Tree-grass coexistence in savanna: Interactions of rain and fire. Journal of Theoretical Biology, 267 (2), pp. 235. doi: 10.1016/j.jtbi.2010.08.012.

[2] Robin W, Siobhan M, Mark R (2000). Grassland Ecosystem. In pilot analysis of global ecosystems. Washington D. C. World Resources Institute.
[3] Maestre FT, Bowker MA, Puche MD, Hinojosa MB, Martinez I, GarciaPalacios P, Castillo AP, Soliveres S, Luzuriaga AL, Sanchez AM, Carreira JA, Gallardo A and Escudero A (2009). Shrub encroachment can reverse desertification in semi-arid Mediterranean grasslands. Ecol. Lett. 12: 930-941.

[4] Auken OV (2009). Causes and consequences of woody plant encroachment into western North American grasslands. J. Environ. Manage. 90: 2931-2942.

[5] Eldridge DJ, Matthew AB, Fernando TM, Erin R, James F, Walter GW (2011). Impacts of shrub encroachment on ecosystem structure and functioning: towards a global synthesis. Ecol. Lett. 14 (7): 709-722.

[6] Andela N, Liu YY, van Dij AIJM, de Jeu RAM, McVicar TR (2013). Global changes in dryland vegetation dynamics (1988-2008) assessed by satellite remote sensing: comparing a new passive microwave vegetation density record with reflective greenness data. Biogeosciences 10: 6657-6676.

[7] Coppock D (1994). The Borana Plateau of Southern Ethiopia: Synthesis of Pastoral Research, Development and Changes 1980-1990. In: System Study No. 5. ILCA, 374 p.

[8] Ayana A (2002). The effect of clearing bushes and shrubs on range condition in Borana, Ethiopia. Trop. Grass. 36: 69-76.

[9] Gemedo D, Brigitte LM, Johannes I (2006). Encroachment of woody plants and its impact on pastoral livestock production in the Borana lowlands, southern Oromia, Ethiopia. Afr. J. Ecol. 44: 237-246.

[10] Ayana A, Gufu O (2010). Effects of grazing pressure, the age of enclosures and seasonality on bush cover dynamics and vegetation composition in southern Ethiopia. J. Arid Environ. 74: 111-120.

[11] Daniel Jeleta (2010). The extent of Bush Encroachment and Its Impacts on Selected Soil Properties in Borana Rangeland, Ethiopia. MSc. Thesis, Hawassa University Wonndo Genet College of Forestry and Natural Resources, Integrated Watershed Management.

[12] Hasen YM (2013). The influence of land use and cover changes on the pastoral rangeland systems of southern Ethiopia - How much woody cover is enough? Ph.D. Thesis, University of Hohenheim.

[13] Chuan Liao, Patrick E. Clark and Stephen D. DeGloria (2018). Bush encroachment dynamics and rangeland management implications in southern Ethiopia. Ecology and Evolution, 8: 11694-11703, DOI: 10.1002/ece3.4621.

[14] Ayana A (2007). The Dynamics of Savanna Ecosystems and Management in Borana, Southern Ethiopia. Ph.D. Thesis, Norwegian University of Life Sciences, Department of International Environment and Development Studies, Ås, Norway.

[15] Ayana, A., \& Oba, G. (2007). Relating long-term rainfall variability to cattle population dynamics in communal rangelands and a government ranch in southern Ethiopia, 94, 715-725. https://doi.org/10.1016/j.agsy.2007.02.012.

[16] Bikila N, Bedasa E, Samuel T, Barecha B, Jaldesa D, Nizam H (2014). Control of bush encroachment in Borana zone of southern Ethiopia: effects of different control techniques on rangeland vegetation and tick populations. Pastoralism 4: 18 . 
[17] Bovey R. W. (2001). Woody plants and woody plant management. ecology, safety, and environmental impact. Marcel Dekker. Inc., New York.

[18] Ayana A, Gufu O, Adunya T (2012). Bush Encroachment Control Demonstrations and Management Implications on Herbaceous Species in Savannas of Southern Ethiopia. Trop. Subtrop. Agroecosyst. 15: 173-185.

[19] Archer, S. R., \& Predick, K. I. (2014). An ecosystem services perspective on brush management: research priorities for competing land-use objectives, 1394-1407.

[20] Friis IB, Demissew S, van Breugel P (2011). Atlas of Potential Vegetation of Ethiopia. Addis Ababa, Ethiopia: Addis Ababa University Press and Shama Books.

[21] Blake G. R and Hartge K. H. (1986). Bulk Density. In K. (ed.), Methods of Soil Analysis, Part 1 America Society of Agronomy, Madison, pp 363-375.

[22] Pearson T, Sarah W, Sandra B (2005). Sourcebook for Landuse, Landuse Change and Forestry Projects. Benoit Bosquet and Lasse Ringius.

[23] Jackson M. L. (1967). Soil Chemical Analysis. New Delhi,: Prentice Hall of India Pvt. Ltd.

[24] Reeuwijk Van L. P. (202). Procedures for Soil Analysis. Food and Agriculture Organization of United satate. International Soil reference and Infroramtion Centre, Wagenigen, Natherland.

[25] Wairiu M. and Lal R. (2003). Soil organic carbon in relation to cultivation and topsoil removal on sloping lands of Kolombangara, Solomon Islands. Soil and Tillage Research, 70 (1), pp. 19-27.

[26] Carter M. R. and Gregorich E. G. (2006). Soil Sampling and Methods of Analysis. (C. M. E. G, Ed.) CRC Press Taylor \& Francis Group: Canadian Society of Soil Science.

[27] Gemedo-Dalle T, Brigitte LM, Johannes I (2005). Plant Biodiversity and Ethnobotany of Borana Pastoralists in Southern Oromia, Ethiopia. Econ. Bot. 59 (1): 43-65.

[28] Edwards S, Mesfin T, Hedberg I (1995). Flora of Ethiopia and Eritrea, Vol. 2 (2), the National Herbarium, Addis Ababa University: Addis Ababa and Department of Systematic Botany, Uppsala University, Uppsala.

[29] Edwards S, Mesfin T, Sebsebe D, Hedberg I (2000). Flora of Ethiopia and Eritrea, Vol. 2 (1), the National Herbarium, Addis Ababa University: Addis Ababa and Department of Systematic Botany, Uppsala University, Uppsala.

[30] Hammer Ø, Harper DAT, Ryan PD (2001). PAST: Paleontological Statistics Software Package for Education and Data Analysis. Palaeontologia Electronica 4 (1): 9.

[31] Dirbaba, N. B., Denboba, M. A., \& Tussie, G. D. (2014). Plant Diversity and Vegetation Structure in Encroached and Nonencroached Areas of Borana Rangelands: The Case of Hallona and Medhacho Pastoralist Associations, 4, 787-796. https://doi.org/10.17265/2161-6256/2014.09.010

[32] Gobelle, S. K., \& Gure, A. (2018). Effects of bush encroachment on plant composition, diversity and carbon stock in Borana rangelands, 10 (May), 230-245. https://doi.org/10.5897/IJBC2017.1143
[33] Worku B and T/Yohannes B (2018) Effect of Post Bush Clearing Management Practice on Herbaceous Species Productivity and Soil Status of Rangelands in Hammer District of South Omo Zone. Journal of Biology, Agriculture and Healthcare, ISSN 2224-3208.

[34] Haussmann, N. S., Kalwij, J. M., and Bezuidenhout, S. (2016). South African Journal of Botany Some ecological side-effects of chemical and physical bush clearing in a southern African rangeland ecosystem. South African Journal of Botany, 102, 234-239. https://doi.org/10.1016/j.sajb.2015.07.012

[35] Alford, A. L., Hellgren, E. C., and Engle, D. M. (2012). Experimental Tree Removal in Tallgrass Prairie: Variable Responses of Flora and Fauna along a Woody Cover Gradient, 22 (3). https://doi.org/10.1890/10-1288.1

[36] Smit, G. N. (2005). Tree thinning as an option to increase herbaceous yield of an encroached semi-arid savanna in South Africa, 15, 1-15. https://doi.org/10.1186/1472-6785-5-4

[37] Belay, T. A., and Moe, S. R. (2015). Assessing the Effects of Woody Plant Traits on Understory Herbaceous Cover in a Semiarid Rangeland. Environmental Management, 165-175. https://doi.org/10.1007/s00267-015-0491-3

[38] Raúl Ochoa-Hueso, Fernando T. Maestre, Asunción de los Ríos, Sergio Valea, Mark R. Theobald, Marta G. Vivanco, Esteban Manrique and Mathew A. Bowker (2013). Nitrogen deposition alters nitrogen cycling and reduces soil carbon content in low-productivity semiarid Mediterranean ecosystems. Environmental Pollution, 179, 185-193.

[39] Sang-Hyun Lee, Seongjun Kim \& Hyun-Jun Kim (2018) Effects of thinning intensity on understory vegetation in Chamaecyparisobtusa stands in South Korea, Forest Science and Technology, 14: 1, 7-15, DOI: 10.1080/21580103.2017.1409661.

[40] Angula Nahas (2016). The Effect of Bush Clearing On Soil Properties, At Cheetah Conservation Fund Farm in Otjozondjupa Region, Namibia. A Thesis Submitted in Partial Fulfilment for the Degree of Master of Arts in Geography and Environmental Studies, University of Namibia, Kenya (unpublished).

[41] Mokgotsi, R. O. (2018). Effects of bush encroachment control in a communal managed area in the Taung region, North West Province, South Africa. An MSc thesis (Botany), North-West University, Potchefstroom Campus, https://orcid.org/00000001-8975-0868.

[42] Abule, E., Smit, G. N. and Snyman, H. A. (2005). The influence of woody plants and livestock grazing on grass species composition, yield and soil nutrients in the Middle Awash Valley of Ethiopia. Journal of Arid Environments, 60: 343-358.

[43] Sankaran, M., Ratnam, J. \& Hanan N. (2008). Woody cover in African savannas: the role of resources, fire and herbivory. Global Ecology \& Biogeography, 17 (2): 236-245.

[44] Lobe I, Amelung W, Du Preez CC (2001) Losses of soil carbon and nitrogen with prolonged arable cropping from sandy soils of the South African Highveld. Eur J Soil Sci 52: 939101. 